\title{
Babesia behnkei sp. nov., a novel Babesia species infecting isolated populations of Wagner's gerbil, Dipodillus dasyurus, from the Sinai Mountains, Egypt
}

Anna Bajer ${ }^{1 *}$, Mohammed Alsarraf $^{1}$, Małgorzata Bednarska ${ }^{1}$, Eman ME Mohallall', Ewa J Mierzejewska', Jolanta Behnke-Borowczyk ${ }^{3}$, Sammy Zalat ${ }^{4}$, Francis Gilbert ${ }^{5}$ and Renata Welc-Falęciak ${ }^{1}$

\begin{abstract}
Background: Although a number of new species of Babesia/Theileria have been described recently, there are still relatively few reports of species from Africa. In this study based on the evaluation of morphology and phylogenetic relationships, we describe a novel species from Wagner's gerbil, Babesia behnkei n. sp.

Methods: Rodents ( $n=1021)$ were sampled in four montane valleys (wadies) in 2000, 2004, 2008 and 2012 in the Sinai Mountains, Egypt. The overall prevalence of Babesia spp. was highest in the Wagner's gerbil (Dipodillus dasyurus; 38.7\%) in comparison to the prevalence in the spiny mice species, Acomys dimidiatus and A. russatus. Morphological investigations were conducted for the comparison of trophozoites of the novel species of Babesia with the B. microti King's 67 reference strain. Thirty-two isolates derived from D. dasyurus over a 9 year period (2004-2012) from two wadies (29 isolates from Wadi Gebel and 3 from Wadi El-Arbaein) were investigated by microscopic, molecular and phylogenetic analysis. A near-full-length sequence of the $18 \mathrm{~S}$ rRNA gene and the second internal transcribed spacer (ITS2) region were amplified, sequenced and used for the construction of phylogenetic trees.
\end{abstract}

Results: A novel species of Babesia was identified in two isolated populations of $D$. dasyurus. Phylogenetic analysis of $18 \mathrm{~S}$ rDNA and ITS2 sequences revealed that $B$. behnkei n. sp. is most closely related to B. lengau from cheetahs from South Africa and to Nearctic species found only in North America (the pathogenic B. duncani and B. conradae) and that it is more distant to the cosmopolitan rodent parasite $B$. microti. Trophozoites of $B$. behnkei were smaller and less polymorphic than trophozoites of B. microti.

Conclusion: Babesia behnkei n. sp. is a novel species of the 'Duncani group' maintained in isolated populations of Dipodillus dasyurus occurring in the Sinai Mountains of Egypt.

Keywords: Babesia, Dipodillus dasyurus, 18S rDNA, ITS2, Phylogenetic analysis, Sinai, Egypt

\footnotetext{
* Correspondence: anabena@biol.uw.edu.pl

'Department of Parasitology, Institute of Zoology, Faculty of Biology,

University of Warsaw, 1 Miecznikowa Street, 02-096 Warsaw, Poland

Full list of author information is available at the end of the article
} 


\section{Background}

The genus Babesia comprises tick-transmitted, intraerythrocytic protozoan parasites of many different vertebrates including humans [1,2]. Currently there are over 120 recognized species of Babesia described from various parts of the world. Even in the last two decades new species have been added to the list, e.g. B. venatorum in humans in Europe, B. benneti in the yellow-legged gull [3], B. hongkongensis in feral cats in Hongkong [4] and a novel Babesia/Theileria species from marsupials in Australia [5].

In contrast to the rest of the world, relatively few new species have been described from African hosts in recent years, including for example B. lengau from cheetahs [6], B. bicornis from black rhinoceros [7], B. ugwidiensis from cormorants [8] and B. leo from lions [9]. Additionally, putative new species of Babesia/Theileria have been reported from sable antelopes [10] and wild felids from Kenya [11]. It is pertinent that new species of Babesia (and presumably also other haemoparasites) are often discovered at post-mortem examinations, especially in the case of endangered host species such as the sable antelope and the black rhinoceros.

The diversity of Babesia spp. depends on many factors, including host-parasite or vector-parasite specificities, well reflected in the geographically restricted distribution of some species. Cosmopolitan species include parasites of livestock and horses (B. bovis, B. divergens, B. equi, B. ovis), dogs or cats (B. canis, B. rossi, B. vogeli, $B$. felis) or rodents (B. microti). Other species are specific to particular hosts whose distribution is restricted to continents, as for example with $B$. conradae, B. duncani or B. odocoilei found in North America, B. benetti, $B$. capreoli, B. venatorum found in Europe, and B. crassa, $B$. hongkongensis, B. motasi, B. orientalis found only in Asia. In this last Asian group of species, some have been identified to date only in a single host species. However, it is also well established that some hosts are susceptible to, and can carry concurrently, more than a single species of Babesia/Theileria; often these species are indistinguishable by conventional microscopy. For example, cats are susceptible to infection with $B$. felis but also with B. leo, B. hongkongensis and B. lengau [4,12,13]. In view of this complexity, it is highly likely that many Babesia spp. remain still unrecognized, especially those infecting rarely studied wild species of hosts in isolated regions of the world.

Conventionally and historically, new species of Babesia have been erected based on their hosts and on morphological criteria. However, the trophozoites of different species of 'small' Babesia and Theileria spp. in erythrocytes appear very similar under light microscopy and their differentiation is difficult. In recent decades however, the use of molecular tools have made a significant impact on the field and the sequencing of selected gene fragments has greatly improved the accuracy and reliability of species identification. However, because of the morphological similarities, the systematics of Babesia/ Theileria spp. are still not fully resolved and in urgent need of revision in view of the many recently conducted molecular phylogenetic studies [14-16]. Based on these, the distant clades of 'Babesia', including some species that were misidentified as 'Theileria' [14], require revision of their generic status and new nomenclature. Thus the use of molecular tools, which are clearly more sensitive than conventional morphology based on light microscopy, remains crucial for distinguishing between and for the identification of Babesia/Theileria spp. and for their assignment to particular clades.

One cosmopolitan species of public health concern is B. microti, the main cause of human babesiosis in the United States of America $[2,17,18]$ but also identified recently in humans in Europe [19,20], China and Japan [21]. This species had been originally described as Smithia microti in Portugal from the vole Microtus incertus [22]; voles of the genus Microtus are still considered to be the main reservoir of this parasite worldwide [22,23]. Surprisingly $B$. microti has subsequently been found in a wide variety of rodent species worldwide [21,22,24-34].

In Eurasia and North America the main rodent hosts of B. microti are different species of voles, Microtus spp., Myodes (Clethrionomys) spp. and mice, Apodemus spp. At least 8 species of Microtus have been reported as commonly infected with $B$. microti: $M$. arvalis, $M$. agrestis and M. oeconomus from Europe [22,32,35,36], M. montebelli from Japan and $M$. miurus, $M$. montanus, $M$. ochrogaster and M. pennsylvanicus from North America [21,33,34,37]. Additionally, 4 species of Myodes (Clethrionomys) ( $M$. glareolus, $M$. gapperi, $M$. rufocanus and $M$. rutilus) and 5 species of Apodemus (A. agrarius, A. argenteus, A. flavicollis, $A$. speciosus and $A$. sylvaticus) have been reported as hosts of $B$. microti worldwide. Peromyscus leucopus has recently been shown to act as a competent host in North America [27] and infected P. keeni have been reported from Alaska [37]. Other species of rodents reported to host $B$. microti include eastern chipmunks Tamias striatus [27]. However, carnivores (i.e. foxes, raccoons) and insectivores such as shrews (at least 5 species of Sorex, Blarina and others) may also serve as hosts of $B$. microti [21,25,27,33-35]. On the basis of the above, B. microti appears to be the most widely distributed species worldwide evidently lacking tight host-specificity, but caution is warranted. Among the many studies on rodent haemoparasites reporting the presence of infections with B. microti [38-42], it is suspected that few have appropriately and critically assessed the species identity; rather it has been merely assumed that the parasite is $B$. microti because it was detected in a rodent host. In fact, recent studies have shown that at least three 
distinct clades, differing in their host-specificity, exist among isolates of $B$. microti that have been genotyped $[43,44]$. Another species of Babesia infecting rodents, $B$. rodhaini, has been used worldwide as a laboratory model in mice and rats; this species seems to be closely related to the 'Microti group' according to phylogentic analysis [14].

Our research on the parasite fauna of wild rodents from the Sinai Mountains began in 2000, when we were invited by Professor Jerzy M. Behnke from the University of Nottingham to join an expedition of the university assessing the helminth communities of wild rodents in four isolated montane valleys. Initially, the study focused on gastrointestinal parasites of Acomys dimidiatus, the most abundant rodent species inhabiting Bedouins' gardens $[45,46]$. Subsequently, intestinal protozoa and haemoparasites were incorporated into the study [38] and the host range extended. The highest prevalence of infections with Babesia and Bartonella spp. were found in the Wagner's gerbil, Dipodillus dasyurus, one of the three most numerous rodent species in the study sites (unpublished data). Primary molecular research on the Babesia-positive samples revealed surprisingly low homology (approx. 96\%) of partial $(550 \mathrm{bp}$ ) $18 \mathrm{~S}$ rDNA sequence to those for B. microti and other named species. Therefore, exploiting material collected in the latter expeditions to the study sites, we characterized this novel species of Babesia by light microscopy study and molecular and phylogenetic analyses.

\section{Methods}

Field studies in Sinai, Egypt

Fieldwork was conducted over 4-5-week periods in August-September 2000, 2004, 2008 and 2012 and was based at the Environmental Research Centre of Suez Canal University (2000, 2004) or at Fox Camp (2008, 2012) in the town of St Katherine, South Sinai, Egypt. Trapping was carried out in four montane wadis (dry valleys) in the vicinity of St Katherine. The local environment and general features of the four study sites (Wadi El-Arbaein, Wadi Gebel, Wadi Itlah and Wadi Gharaba), as well as their spatial relationships with one another, have been described elsewhere [46]. At each site, rodents were caught live in Sherman traps, placed selectively among the rocks and boulders around walled gardens and occasionally along the lower slopes of wadis. These were set out at dusk, and inspected in the early morning before exposure to direct sunlight. All traps were brought to the local or main camp, where the animals were identified and processed. Traps were re-set the following evening.

The three most abundant rodent species (A. dimidiatus, A. russatus and $D$. dasyurus) (Table 1 ) were sampledsexed, weighed, measured and scrutinized for obvious lesions as described by [46]. Ectoparasites observed during field examination were removed and placed in 70\% ethanol. Blood and faecal samples were taken and animals were then either fur marked individually and released close to the point of capture (Figure 1A), or returned to the main camp at St Katherine for autopsy. A maximum

Table 1 Structure of the rodent communities sampled and numbers of hosts studied during 2000-2012

\begin{tabular}{|c|c|c|c|c|c|c|c|}
\hline \multirow[t]{2}{*}{ Year of study } & \multirow[t]{2}{*}{ Host species } & \multicolumn{4}{|l|}{ Site (wadi) } & \multicolumn{2}{|l|}{ No. of rodents } \\
\hline & & W. El Arbaein & W. Gebel & W. Gharaba & W. Itlah & Total by species & Total by year \\
\hline \multirow[t]{3}{*}{2000} & Acomys dimidiatus & 58 & 28 & 28 & 46 & 160 & \\
\hline & Acomys russatus & 4 & 4 & 1 & 6 & 15 & \\
\hline & Dipodillus dasyurus & 3 & 6 & 2 & 2 & 13 & 188 \\
\hline \multirow[t]{3}{*}{2004} & Acomys dimidiatus & 43 & 43 & 60 & 70 & 216 & \\
\hline & Acomys russatus & 1 & 8 & 3 & 8 & 20 & \\
\hline & Dipodillus dasyurus & 4 & 16 & 7 & 0 & 27 & 263 \\
\hline \multirow[t]{3}{*}{2008} & Acomys dimidiatus & 66 & 43 & 52 & 80 & 241 & \\
\hline & Acomys russatus & 3 & 6 & 3 & 8 & 20 & \\
\hline & Dipodillus dasyurus & 2 & 15 & 2 & 0 & 19 & 280 \\
\hline \multirow[t]{3}{*}{2012} & Acomys dimidiatus & 64 & 46 & 52 & 58 & 220 & \\
\hline & Acomys russatus & 0 & 7 & 2 & 9 & 18 & \\
\hline & Dipodillus dasyurus & 14 & 22 & 16 & 0 & 52 & 290 \\
\hline \multirow[t]{3}{*}{ Total by site } & Acomys dimidiatus & 231 & 160 & 192 & 254 & 837 & \\
\hline & Acomys russatus & 8 & 25 & 9 & 31 & 73 & \\
\hline & Dipodillus dasyurus & 23 & 59 & 27 & 2 & 111 & \\
\hline Overall & Total no. of rodents & 262 & 244 & 228 & 287 & & 1021 \\
\hline
\end{tabular}




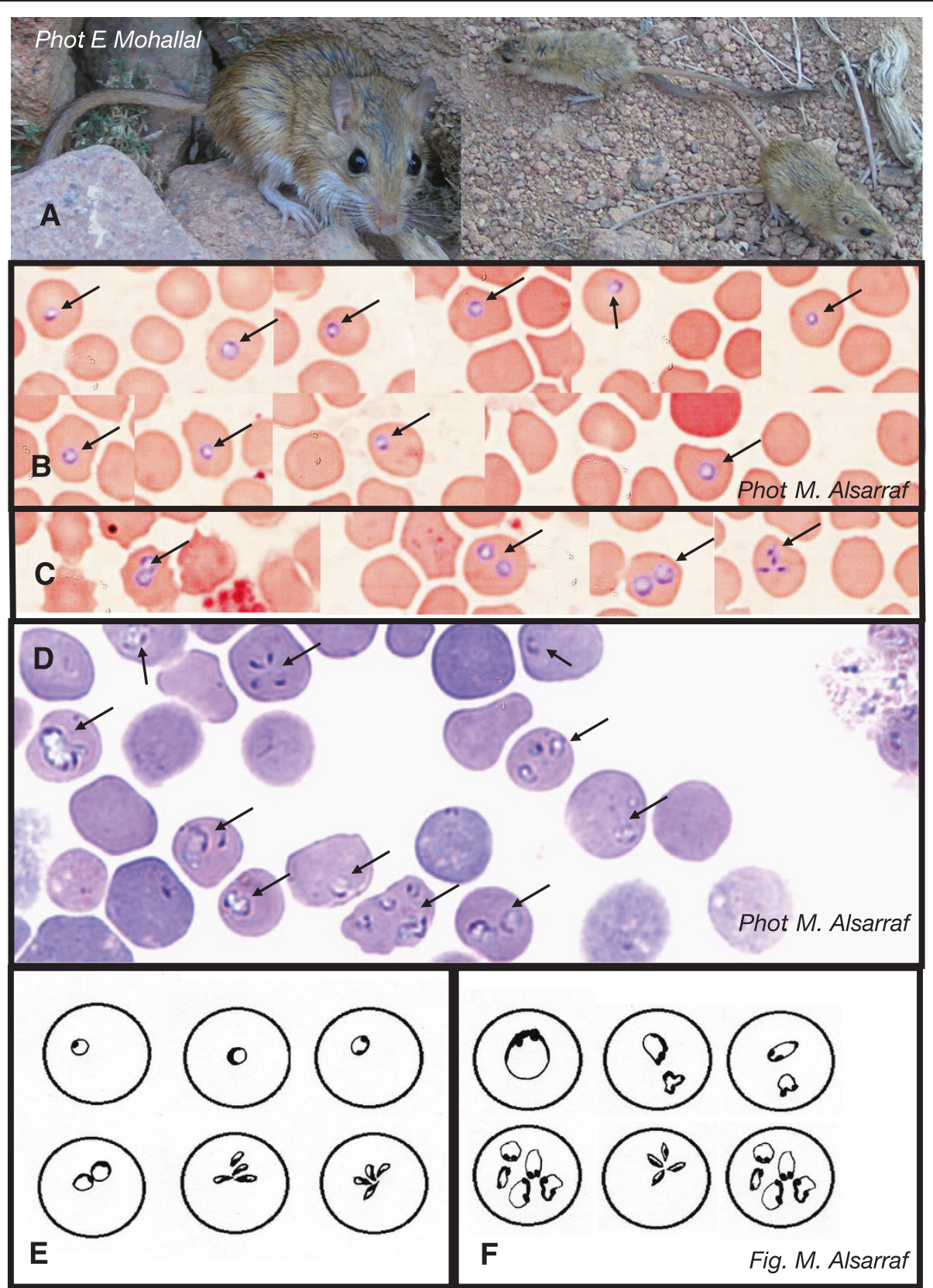

Figure 1 The type-host, Wagner's gerbil Dipodillus dasyurus (W. Gebel) trapped in Sinai, Egypt, and type-forms of Babesia behnkei n. sp. A. Type host: Wagner's gerbil, Dipodillus dasyurus (W. Gebel, Sinai, Egypt). B. Type-forms of Babesia behnkei n. sp. ex Wagner's gerbil Dipodillus dasyurus (W. Gebel) collected in Sinai, Egypt. Typical forms - single rounded trophozoites in erythrocytes. C. Double trophozoites and dividing form (tetrad) of Babesia behnkei n. sp. ex Wagner's gerbil Dipodillus dasyurus in erythrocytes. D. Trophozoites of Babesia microti King's 67 in erythrocytes of BALB/c mice (acute phase, on the $8^{\text {th }}$ day post infection). E. Different forms of Babesia behnkei n. sp. ex D. dasyurus. F. Different forms of Babesia microti from $B A L B / c$ mice.

of $40 \%$ of the captured rodents from each site were culled (by agreement with the St Katherine National Protectorate authorities).

\section{Blood collection and DNA extraction}

Thin blood smears were prepared from drops of blood taken from the heart or tail tip. Blood smears were air- dried, fixed in absolute methanol and stained for $1 \mathrm{~h}$ in Giemsa stain in buffer at pH 7.2. In 2004, 2008 and 2012, in addition to blood smears, molecular techniques were used for the detection of Babesia spp. Blood from the tail vein was collected on FTA classic cards (Whatman, UK) for the long-time preservation of DNA. From the culled animals, $200 \mu \mathrm{l}$ of whole blood were also collected into 
$0.001 \mathrm{M}$ EDTA and frozen at $-20^{\circ} \mathrm{C}$. Genomic DNA was extracted from whole blood using DNAeasy Blood \& Tissue kit (Qiagen, USA) or AxyPrep MiniPrep Blood kit (AxyGen, USA) and stored at $-20^{\circ} \mathrm{C}$. DNA from FTA cards was cleaned with FTA purification Reagent (Whatman, UK) accordingly to manufacturer's instructions.

\section{Molecular characterization}

Detection and genotyping of 32 Babesia isolates (Table 2) were performed by amplification and sequencing of ITS1, ITS2 and 18S rRNA regions/genes. The primers and thermal profiles used in this study have been described previously [7,10,47-50]. Reactions were performed in $1 \times$ PCR buffer, $1 \mathrm{U}$ Taq polymerase, $1 \mu \mathrm{M}$ of each primer and 2-5 $\mu \mathrm{l}$ of the extracted DNA sample. Negative controls were performed in the absence of template DNA. Primers GF (5'-G(C/T) (C/T)T TGT AAT TGG AAT GAT GG-3') and GR (5'-CCA AAG ACT TTG ATT TCT CTC-3') were used for the detection of Babesia/ Theileria spp. by the amplification of a $559 \mathrm{bp}$ fragment of the 18S rDNA $[48,49]$. Primers Nbab_1F (5'-AGC CAT GCA TGT CTA AGT ATA AGC TTT T-3') [10] and TB Rev (5'-AAT AAT TCA CCG GAT CAC TCG-3') [50] were used for the genetic characterization of positive isolates by the amplification of a 1,700 bp near-full-length sequence of the $18 \mathrm{~S}$ rRNA gene. As a second genetic marker, the 315 bp of the ITS2 region were amplified using the primers ITS2-F (5'-GGC TCA CAC AAC GAT GAA GG-3') and ITS2-R (5'-CTC GCC GTT ACT AAG GGA ATC-3') $[7,47]$. Additionally, a 615 bp sequence of the 18S-ITS1$5.8 \mathrm{~S}$ region was amplified using the primers ITS1-F (5'-CGA GTG ATC CGG TGA ATT ATT C-3') and ITS1-R (5'-CCT TCA TCG TTG TGT GAG CC-3') $[7,47]$. PCR products were subjected to electrophoresis on a $1.5 \%$ agarose gel, stained with Midori Green stain (Nippon Genetics, $\mathrm{GmbH}$ ) and sequenced by a private company (Genomed S.A., Poland).

\section{Sequence analysis}

DNA sequence alignments and phylogenetic analyses were conducted using MEGA v. 6.0 [51]. Akaike information criterion was used in jModel Test to identify the most appropriate model of nucleotide substitution. Tamura 3-parameter $(I+G)$ model was chosen as the most appropriate for the Maximum Likelihood analysis of the $18 \mathrm{~S}$ rDNA alignment. Neighbor-Joining method was used as the tree construction method for ITS2 (MEGA v. 6.0), with Kimura 2-parameter model.

Sequences of species/strains of Babesia, Theileria and Cytauxzoon obtained from GenBank (www.ncbi.nlm.nih. gov) were used in the sequence alignment. The stability of inferred phylogenies was assessed by bootstrap analysis of 1,000 randomly generated sample trees.

\section{Morphology by light microscopy}

Giemsa stained blood smears were examined under oil immersion (at $\times 1000$ magnification). Parasites (Babesia spp., Bartonella spp., Haemobartonella (Mycoplasma) spp., Hepatozoon spp. and Trypanosoma spp.) were counted in 200 fields of vision. For comparison, stained blood smears prepared from BALB/c mice infected with B. microti King's 67 strain were also examined [52]. Trophozoites of Babesia spp. were measured with a Nikon screw micrometer calibrated against a standard stage micrometer. Images of the novel Babesia forms were made with a digital camera integrated with Nikon Eclipse E600. Typical forms, characteristic of the isolates were drawn on the basis of more than 100 images.

\section{Statistical analysis}

Quantitative data reflecting the mean diameter of trophozoites were compared between $B$. behnkei $\mathrm{n}$. sp. and B. microti King's 67 strain. The mean diameters were analyzed by multifactorial ANOVA with SPSS v. 21 using models with normal errors.

\section{Ethical issue}

Rodents from St Katherine National Protectorate were sampled by agreement with the St Katherine National Protectorate authorities obtained for each set of field work. B. microti strain King's 67, originally obtained from Dr. S. Randolph (Oxford University) is maintained in our laboratory by weekly blood passage in adult BALB/c females. Blood sampling was carried out in strict accordance with the recommendations in the Guide for the Care and Use of Laboratory Animals of National Ethics Committee for Animal Experimentation, Poland. The protocol no

Table 2 Origin of the isolates of B. behnkei n. sp. from Dipodillus dasyurus used for genotyping and phylogenetic analysis

\begin{tabular}{llllll}
\hline Year of study & W. El-Arbaein & W. Gebel & W. Gharaba & W. Itlah & All sites \\
\hline 2004 & 0 isolates & 12 isolates & nd & nd & 12 isolates (W. Gebel) \\
2008 & 1 isolate & 3 isolates & nd & nd & 4 isolates (1 isolate W. El Arbaein, 3 isolates W. Gebel) \\
2012 & 2 isolates & 14 isolates & nd & nd & 16 isolates (2 isolates W. El Arbaein, 14 isolates W. Gebel) \\
Total & 3 isolates & 29 isolates & nd & nd & 32 (3 isolates W. El Arbaein, 29 isolates W. Gebel) \\
\hline
\end{tabular}

Nd- not done, no isolates available. 
214/2011 was approved by First Warsaw Local Ethics Committee for Animal Experimentation.

\section{Results}

Taxonomic review

Babesia behnkei n. sp.

Type-host: Wagner's gerbil, Dipodillus dasyurus (Rodentia, Muridae, Gerbillinae).

Type-locality: Wadi Gebel in Sinai Mountains, Egypt.

Other localities: Wadi El-Arbaein in Sinai Mountains, Egypt.

Type-material: Hapanotype. Eg085 from Dipodillus dasyurus, sampled on 22 August 2004 in Wadi Gebel, Sinai Mountains, Egypt, deposited at the Natural History Museum, London, UK (NHMUK 2014.8.26.1).

Parahapanotypes. Eg083 (NHMUK 2014.8.26.2), Eg084 (NHMUK 2014.8.26.3) from D. dasyurus, sampled on 22 August 2004 in Wadi Gebel, Sinai Mountains, Egypt; Eg041(NHMUK 2014.8.26.4) from D. dasyurus, sampled on 17 August 2008, W. El-Arbaein, Sinai Mountains, Egypt; Eg026 (NHMUK 2014.8.26.5), Eg028 (NHMUK 2014.8.26.6) from D. dasyurus sampled on 17 August 2012, W. El-Arbaein, Eg089 (NHMUK 2014.8.26.7), Eg091 (NHMUK 2014.8.26.8) from D. dasyurus, sampled on 21 August 2012 W. Gebel, Sinai Mountains, Egypt; all deposited at the Natural History Museum, London, UK.

Vector: currently unknown, but assumed to be a local species of ixodid tick.

Representative sequences: GenBank KJ908691 (18S rRNA gene); KJ908692 (ITS2 region); KM067276 (ITS1 region).

Etymology: The species is named for Professor Jerzy M. Behnke, the pioneer and the leader of studies on rodent parasites from isolated wadis in the Sinai Mountains of Egypt.

ZooBank reference numbers: pub: D3D8C6F4-796B4E93-9DE4-CD6B7897E169

act: 7491E249-3966-4170-AC52-6D521D988672

Description

The organism is a typical small species of Babesia, with trophozoites occupying central to subcentral position within host erythrocytes (Figures 1B, E). On Giemsa stained slides, the cytoplasm is pale with a purple-staining nucleus around the periphery (Figure 1B, C). Trophozoites are mainly rounded, rarely slightly ovoid, less polymorphic than trophozoites of B. microti King's 67 observed in BALB/C mice (Figure 1B-F). Trophozoite dimensions (diameter) of $B$. behnkei n. sp. were significantly smaller than those of $B$. microti King's 67 [range 0.5-2.2 $\mu \mathrm{m}$, mean $\pm \mathrm{SD}$ $1.26 \pm 0.35 \mu \mathrm{m}(\mathrm{n}=212)$ vs range 0.6-3.0 $\mu \mathrm{m}$, mean $1.46 \pm 0.56 \mu \mathrm{m}(\mathrm{n}=50) ; \mathrm{F}_{1,261}=8.48, P=0.004$, respectively]. Dividing forms, tetrads (resembling the Maltese cross) were observed and sometimes two forms in one red cell were recorded (Figure 1C).

\section{Field studies: ecology of Babesia behnkei n. sp.}

Altogether, 1,021 rodents from the Sinai Mountains, Egypt, were sampled in four montane valleys (wadies) in 2000, 2004, 2008 and 2012, including 837 individuals of the spiny mouse Acomys dimidiatus, 73 A. russatus and 111 Wagner's gerbils Dipodillus dasyurus (Table 1). Overall prevalence of Babesia spp. was the highest in Wagner's gerbil (38.7\%, Table 3) in comparison with A. dimidiatus or $A$. russatus ( $<10 \%$, data not presented). Infections with $B$. behnkei were identified only in two isolated populations of $D$. dasyurus, from Wadi Gebel (66.1\%) and from W. El-Arbaein (17.4\%). Parasites were maintained in these populations over a period of at least 9 years, 2004-2012 (Table 3).

\section{Genotyping and phylogenetic analysis}

Thirty two isolates derived from $D$. dasyurus obtained over a 9 year period from two wadies (29 isolates from Wadi Gebel and 3 from Wadi El-Arbaein) (Table 2) were investigated by the analysis of near-full-length sequence of the $18 \mathrm{~S}$ rRNA gene. All sequences were identical, indicating the presence of a single parasite species. A BLAST search in GenBank revealed no identical sequences in the database, therefore this new species was designated as Babesia behnkei n. sp. The highest homology (about 96\%) found was with $B$. lengau from cheetahs [6] and with $B$. vesperuginis from bats Pipistrellus spp. in Cornwall, UK [53]. The $18 \mathrm{~S}$ rRNA sequence for Babesia behnkei n. sp. differed from that for $B$. lengau by 43 nucleotides and from that for $B$. microti by 55 nucleotides (Additional file 1).

The phylogenetic analyses including sequences for Babesia behnkei n. sp. and for other species of Babesia/ Theileria were conducted in MEGA v. 6.0 as detailed in

Table 3 Prevalence of B. behnkei n. sp. in Wagner's gerbils: no. of infected/examined hosts (prevalence in \%)

\begin{tabular}{llllll}
\hline Year of study & W. El-Arbaein & W. Gebel & W. Gharaba & W. Itlah & All sites \\
\hline 2000 & $0 / 3(0)^{*}$ & $0 / 6(0)^{*}$ & $0 / 2(0)^{*}$ & $0 / 2(0)^{*}$ & $0 / 13(0)^{*}$ \\
2004 & $1 / 4(25)$ & $15 / 16(93.8)$ & $0 / 7(0)$ & $0 / 0$ & $16 / 27(59.3)$ \\
2008 & $1 / 2(50)$ & $6 / 15(40)$ & $0 / 2(0)$ & $0 / 0$ & $7 / 19(36.8)$ \\
2012 & $2 / 14(14.3)$ & $18 / 22(81.8)$ & $0 / 16(0)$ & $0 / 0$ & $20 / 52(38.5)$ \\
Total by site & $4 / 23(17.4)$ & $39 / 59(66.1)$ & $0 / 27(0)$ & $0 / 2(0)$ & $43 / 111(38.7)$ \\
\hline
\end{tabular}

*Prevalence only on the basis of microscopy; no DNA samples available for PCR. 
the Methods section [51]. A representative tree for $18 \mathrm{~S}$ rDNA sequences, obtained using the Maximum Likelihood method and a Tamura 3-parameter $(\mathrm{I}+\mathrm{G})$ model is presented in Figure 2. Babesia behnkei n. sp. clustered in a monophyletic group/clade with the African species $B$. lengau and with American zoonotic species B. duncani (Babesia WA1) and canine parasite B. conradae ('Duncani group'[14]). This clade was distinct from Babesia spp. (sensu stricto), i.e. B. bovis, B. canis, B. gibsoni, B. venatorum [EU1] and $B$. divergens, as well as from the main Theileria spp. clade including $T$. annulata, and from the zoonotic and non-zoonotic B. microti strains (Figure 2).

Phylogenetic analysis of an approximately 315 bp region of ITS2 of four isolates by the neighbour-joining method with the Kimura two-parameter distance calculation revealed very similar results (Figure 3). Babesia behnkei n. sp. formed a monophyletic group with the American species and strains, B. duncani (Babesia WA1), B. conradae and others ('Duncani group'[14]), and with the African $B$. lengau. Again, this clade was distant from Babesia spp. (sensu stricto), i.e. B. divergens, B. major and B. gibsoni, as well as from the main Theileria clade with $T$. parva, and from $B$. microti and related species (B. rodhaini and B. felis) (Figure 3).

Comparison of the ITS2 sequences for Babesia behnkei n. sp. with those for other species (B. lengau, B. duncani and $B$. microti) revealed low homology (Additional file 2). Similarly, the ITS1 sequence displayed low homology with a few known sequences for Babesia spp., including $B$. microti (Additional file 3).

\section{Discussion}

Microscopic, molecular and phylogenetic analysis of the Babesia sp. infecting Wagner's gerbil from the Sinai Mountains supported its differentiation from all known species and consequently the naming of a novel rodent species of piroplasms was justified. Infections with Babesia behnkei n. sp. were found in two isolated populations of D. dasyurus during a 9 year period (2004-2012). This novel species belongs to the 'Duncani group' (Clade VI) and is closely related to $B$. lengau and the human-infecting parasite $B$. duncani from North America.

Morphologically, Babesia behnkei n. sp. is indistinguishable from other small Babesia spp. but seems less polymorphic than B. microti. Dividing forms were observed rarely and parasitaemia exceeded 100 parasites per 200 fields of vision at $\times 1000$ magnification in only 5 individuals. The majority of parasite trophozoites were regular and rounded.

Molecular and phylogenetic analysis of two widely used molecular markers (18S rDNA and ITS2) revealed that Babesia behnkei n. sp. is distinct from other known rodent Babesia spp. (B. microti and B. rodhaini), Babesia (sensu stricto) and Theileria spp. Analysis of both loci placed the new species in a recently distinguished 'Duncani group' (Clade VI [14]). This group is interesting because it consists of only a few named species and several unnamed piroplasms, including some pathogenic for humans $[6,14]$. Among the established species, there are two from North America, B. duncani (previously Babesia WA1), identified as an etiologic agent in human cases of babesiosis in western states of the USA [54], and B. conradae, described from a dog in California [55,56]. Among the parasites of the 'Duncani group', there is only one species from Africa, B. lengau, identified recently in cheetahs from South Africa [6]. However, another new strain/ species of Babesia related to B. lengau, has been found recently in spotted hyenas from South Africa [57]; the latter still requires formal description. It is highly likely that this clade of piroplasms will be expanded in the future with new molecular studies on parasites from host species that have yet to be examined in Africa, America and elsewhere.

The pathogenicity of known and new Babesia species/ strains differs extensively even among species from a single phylogenetic group. Babesia lengau appears to be nonpathogenic for cheetahs but is pathogenic for cats $[6,12]$. Babesia conradae causes haemolytic anaemia in dogs in California [55,56] and B. duncani may infect humans with an intact spleen or asplenic individuals, and infections in humans were reported to be subclinical or severe [17]. We have not observed any obvious symptoms of babesiosis in the Wagner's gerbil (i.e. brown colored urine, chills, apathy).

Cases of human babesiosis have been recorded in Egypt [58-60] and interestingly, both North and South Sinai (our study site) governorates are considered to be endemic regions for babesiosis in Egypt [61]. The number of reported cases differs [33,61] and so far no molecular identification of the Babesia spp. involved in human cases has been carried out. The number of molecular studies on Babesia spp. infections in Egyptian ticks is also extremely limited and the results of the few published studies certainly need verification, i.e. the presence of $B$. venatorum (EU1) in ticks Ixodes ricinus or of B. microti, B. venatorum (EU1) and B. bigemina in rats/gerbils from Sinai Peninsula [62]. Because of the occurrence of human babesiosis in South Sinai, the high prevalence of $B$. behnkei n. sp. in a common rodent species from the region, the Wagner's gerbil, and the close relationship between $B$. behnkei and the pathogenic $B$. duncani, the possibility of human infection with this novel species should be considered. Our as yet unpublished data indicate that the most common tick in the studied area is the camel tick, Hyalomma dromedarii, which also attaches to and feeds on humans. This tick species is certainly the main candidate for a possible vector of the new species of Babesia, especially because its 


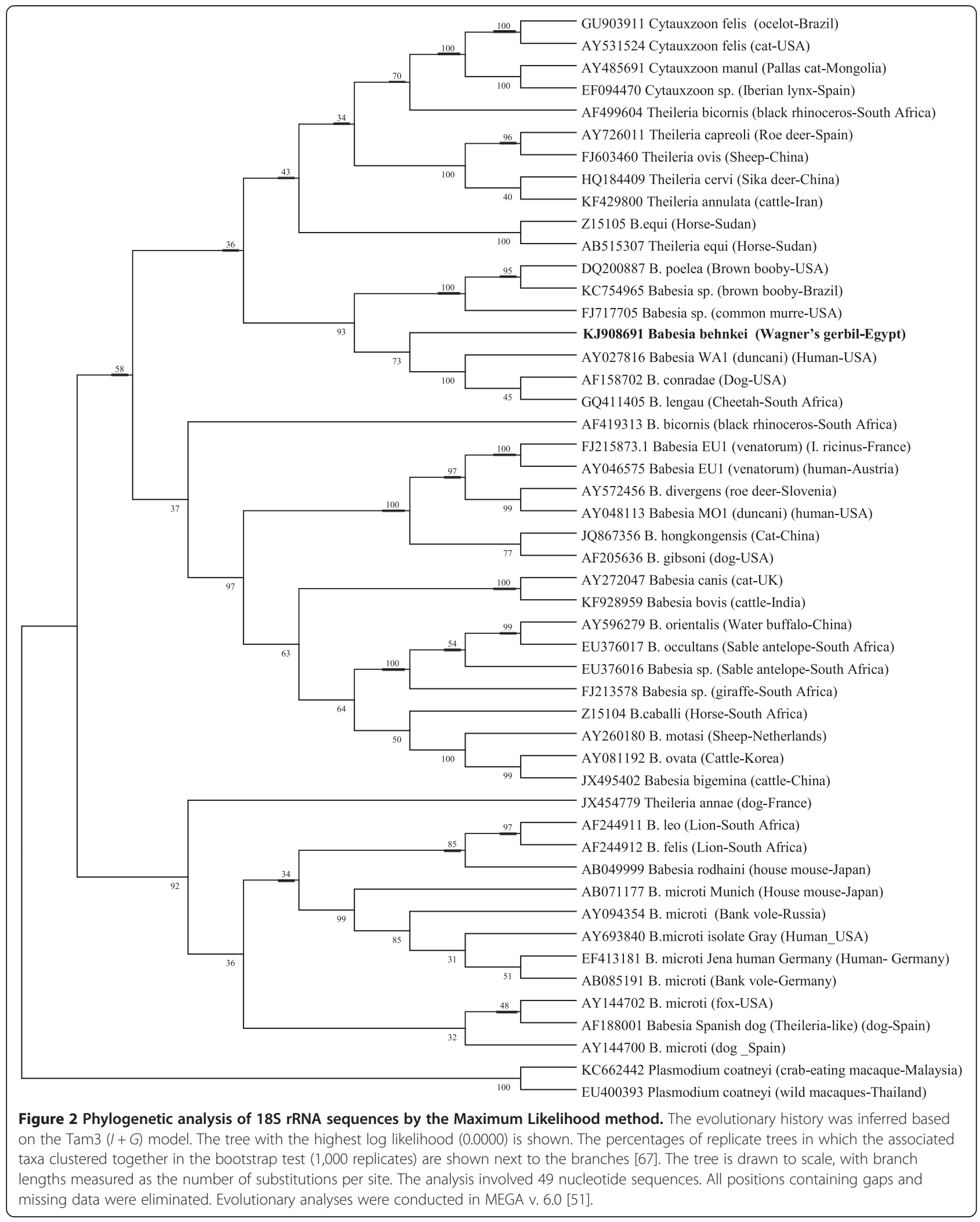




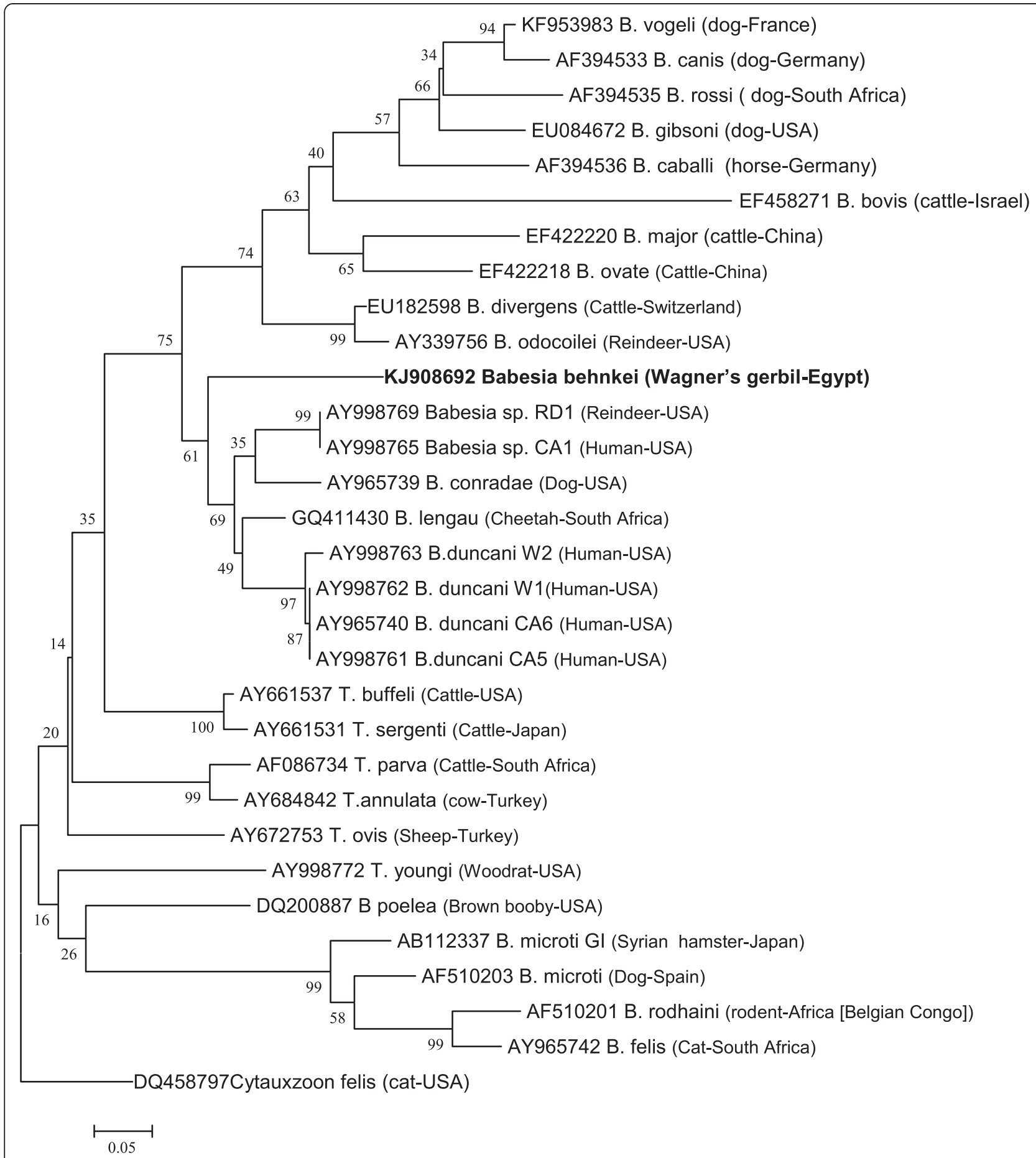

Figure 3 Evolutionary relationships of the taxa based on ITS2 sequences. The evolutionary history was inferred using the Neighbor-Joining method [68]. The optimal tree with the sum of branch length $=3.34829688$ is shown. The percentages of replicate trees in which the associated taxa clustered together in the bootstrap test (1,000 replicates) are shown next to the branches [67]. The tree is drawn to scale, with branch lengths in the same units as those of the evolutionary distances used to infer the phylogenetic tree. The evolutionary distances were computed using the Kimura 2-parameter method [69] and are in the units of the number of base substitutions per site. The analysis involved 31 nucleotide sequences. All positions containing gaps and missing data were eliminated. There were a total of 107 positions in the final dataset. Evolutionary analyses were conducted in MEGA v. 6.0 [51]. 
juvenile stages were found feeding on rodents in Egypt [63]. Juvenile ticks were also collected from rodents in our study and we plan to screen these for the presence of the diagnostic marker for $B$. behnkei and hence to determine their role as a vector of $B$. behnkei in the region.

Dipodillus (Gerbillus) dasyurus was the second most numerous rodent species sampled throughout the 13 years of field work in Sinai. This solitary, burrowing species occurs in a variety of arid habitats, including desert, semi-desert and rocky habitats in hill country [64]. It is a common species, distributed mainly in the Nile Delta, the Sinai, Syria, Iraq and the Arabian Peninsula and it is listed as of Least Concern in the IUCN Red List of Threatened Species. Interestingly, we were able to amplify Babesia spp. DNA only from this host species, so it is likely that host specificity of B. behnkei n. sp. is high and that despite the concerns expressed above, it may not constitute a zoonotic treat to people in the region. The wide geographic range of $D$. dasyurus represents a particular challenge for the study of the distribution of the novel species of Babesia. On the other hand, the high rate of infection in gerbils registered in only two isolated wadis and the absence of the parasite throughout the period of study in other neighboring wadis, support the idea that B. behnkei might have evolved locally in these semi-isolated mountain populations of Wagner's gerbils. In our studies on helminth communities in the same study sites, marked differences in community structure were noted between wadis [46]. Similarly, the prevalence of the intestinal protozoa and other haemoparasites (Trypanosoma spp., Hepatozoon spp.) differed markedly between rodent populations inhabiting these four sites [38]. Each wadi thus presents its own particular challenges for the animals that live there and local adaptation of parasites to their hosts and vice versa is to be expected $[65,66]$. In this particular case, B. behnkei n. sp. showed generally high prevalence (25-90\%) in two wadis and was not detected at all in the other two of the four study sites monitored. Where present, it occurred in Wagner's gerbils in each of the three surveys conducted over a period of 9 years (2004, 2008 and 2012). The Sinai Massif and its associated deep wadis constitute therefore an ideal location for studies of this type, testing the idea that parasites evolve and adapt locally to their hosts and assessing the role of gene flow and metapopulation structure for both hosts and parasites. In future work we hope to unravel further the intricacies of these relationships in the region, notably for haemoparasites such as B. behnkei.

\section{Conclusion}

In conclusion, both ecological, phenotypic and phylogenetic analyses reported in this paper support the recognition of a new piroplasm, B. behnkei n. sp., infecting isolated populations of Wagner's gerbil in Sinai as a distinct species.

\section{Additional files}

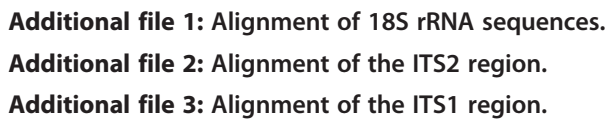

Competing interests

The authors declare that they have no competing interests.

\section{Authors' contributions}

$A B$ designed the study and supervised laboratory and field analyses, MA and RWF performed molecular and phylogenetic studies, MB participated in biological characterization of novel Babesia and supplied reference B. microti strain, FG and SZ organized and supervised field work in Sinai, EJM, JBB, EMEM performed the laboratory and field studies and drafted the manuscript. All authors read and approved the final version of the manuscript.

\section{Acknowledgements}

This study was funded by the National Science Center (NCN), Poland, grant OPUS 2011/03/B/NZ6/02090. Each of the surveys was contributed to by undergraduate students from the University of Nottingham and travel and accommodation funds were generously provided by the University, the British Ecological Society (2010) and the Royal Society (2006 and 2010 to Professor Jerzy M. Behnke) for which we are most grateful. We also acknowledge the support and hospitality shown us by St Katherine protectorate workers and local Bedouins. We would like to acknowledge Professor Jan Kwiatowski, University of Warsaw, for his expert advice on the phylogenetic analyses.

\section{Author details}

${ }^{1}$ Department of Parasitology, Institute of Zoology, Faculty of Biology, University of Warsaw, 1 Miecznikowa Street, 02-096 Warsaw, Poland. ²Desert Research Center, Cairo, Egypt. ${ }^{3}$ Department of Forest Phytopathology, Faculty of Forestry, Poznań University of Life Sciences, Poznań, Poland. ${ }^{4}$ Department of Zoology, Suez Canal University, Ismailia, Egypt. ${ }^{5}$ Faculty of Medicine \& Health Sciences, School of Biology, University of Nottingham, Nottingham, UK.

Received: 31 July 2014 Accepted: 25 November 2014 1. 0 .

\section{References}

1. Hildebrandt A, Gray JS, Hunfeld KP: Human babesiosis in Europe: what clinicians need to know. Infection 2013, 41:1057-1072.

2. Homer MJ, Aguilar-Delfin I, Telford SR 3rd, Krause PJ, Persing DH: Babesiosis. Clin Microbiol Rev 2000, 13:451-469.

3. Merino S: Babesia bennetti n. sp. from the yellow-legged gull (Larus cachinnans, Aves, Laridae) on Benidorm Island, Mediterranean Sea. J Parasitol 1998, 84:422-424.

4. Wong SS, Poon RW, Hui JJ, Yuen KY: Detection of Babesia hongkongensis sp. nov. in a free-roaming Felis catus cat in Hong Kong. J Clin Microbiol 2012, 50:2799-2803.

5. Paparini A, Ryan UM, Warren $K$, Mclnnes LM, de Tores $P$, Irwin PJ: Identification of novel Babesia and Theileria genotypes in the endangered marsupials, the woylie (Bettongia penicillata ogilbyi) and boodie (Bettongia lesueur). Exp Parasitol 2012, 131:25-30.

6. Bosman AM, Oosthuizen MC, Peirce MA, Venter EH, Penzhorn BL: Babesia lengau sp. nov., a novel Babesia species in cheetah (Acinonyx jubatus, Schreber, 1775) populations in South Africa. J Clin Microbiol 2010, 48:2703-2708.

7. Nijhof AM, Penzhorn BL, Lynen G, Mollel JO, Morkel P, Bekker CP, Jongejan F: Babesia bicornis sp. nov. and Theileria bicornis sp. nov.: tick-borne parasites associated with mortality in the black rhinoceros (Diceros bicornis). J Clin Microbiol 2003, 41:2249-2254.

8. Peirce MA, Parsons NJ: Babesia ugwidiensis, a new species of avian piroplasm from Phalacrocoracidae in South Africa. Parasite 2012, 19:375-379. 
9. Penzhorn BL, Kjemtrup AM, Lopez-Rebollar LM, Conrad PA: Babesia leo n. sp. from lions in the Kruger National Park, South Africa, and its relation to other small piroplasms. J Parasitol 2001, 87:681-685.

10. Oosthuizen MC, Zweygarth E, Collins NE, Troskie M, Penzhorn BL: Identification of a novel Babesia sp. from a sable antelope (Hippotragus niger Harris, 1838). J Clin Microbiol 2008, 46:2247-2251.

11. Githaka N, Konnai S, Kariuki E, Kanduma E, Murata S, Ohashi K: Molecular detection and characterization of potentially new Babesia and Theileria species/variants in wild felids from Kenya. Acta Trop 2012, 124:71-78.

12. Bosman AM, Oosthuizen MC, Venter EH, Steyl JC, Gous TA, Penzhorn BL: Babesia lengau associated with cerebral and haemolytic babesiosis in two domestic cats. Parasit Vectors 2013, 6:128.

13. Bosman AM, Venter EH, Penzhorn BL: Occurrence of Babesia felis and Babesia leo in various wild felid species and domestic cats in Southern Africa, based on reverse line blot analysis. Vet Parasitol 2007, 144:33-38.

14. Lack JB, Reichard MV, Van Den Bussche RA: Phylogeny and evolution of the Piroplasmida as inferred from 18S rRNA sequences. Int J Parasitol 2012, 42:353-363.

15. Allsopp MT, Allsopp BA: Molecular sequence evidence for the reclassification of some Babesia species. Ann N Y Acad Sci 2006, 1081:509-517.

16. Criado-Fornelio A, Martinez-Marcos A, Buling-Sarana A, Barba-Carretero JC: Molecular studies on Babesia, Theileria and Hepatozoon in southern Europe. Part II. Phylogenetic analysis and evolutionary history. Vet Parasitol 2003, 114:173-194

17. Gray J, Zintl A, Hildebrandt A, Hunfeld KP, Weiss L: Zoonotic babesiosis: overview of the disease and novel aspects of pathogen identity. Ticks Tick-borne Dis 2010, 1:3-10.

18. Herwaldt BL, Linden JV, Bosserman E, Young C, Olkowska D, Wilson M: Transfusion-associated babesiosis in the United States: a description of cases. Ann Intern Med 2011, 155:509-519.

19. Hildebrandt A, Hunfeld KP, Baier M, Krumbholz A, Sachse S, Lorenzen T, Kiehntopf M, Fricke HJ, Straube E: First confirmed autochthonous case of human Babesia microti infection in Europe. Eur J Clin Microbiol Infect Dis 2007, 26:595-601.

20. Welc-Falęciak R, Pawełczyk A, Radkowski M, Pancewicz SA, Zajkowska J, Siński E: First report of two asymptomatic cases of human infection with Babesia microti (Franca, 1910) from Poland. Ann Agric Environ Med 2014. in press.

21. Zamoto A, Tsuji M, Wei Q, Cho SH, Shin EH, Kim TS, Leonova GN, Hagiwara K, Asakawa M, Kariwa H, Takashima I, Ishihara C: Epizootiologic survey for Babesia microti among small wild mammals in northeastern Eurasia and a geographic diversity in the beta-tubulin gene sequences. J Vet Med Sci 2004, 66:785-792.

22. Karbowiak G: Zoonotic reservoir of Babesia microti in Poland. Pol J Microbiol 2004, 53(Suppl):61-65

23. Karbowiak G, Stanko M, Rychlik L, Nowakowski W, Siuda K: The new data about zoonotic reservoir of Babesia microti in small mammals in Poland. Acta Parasitol 1999, 44:142-144.

24. Beck R, Vojta L, Curkovic S, Mrljak V, Margaletic J, Habrun B: Molecular survey of Babesia microti in wild rodents in central Croatia. Vector Borne Zoonotic Dis 2011, 11:81-83.

25. Clark K, Savick K, Butler J: Babesia microti in rodents and raccoons from northeast Florida. J Parasitol 2012, 98:1117-1121.

26. Duh D, Petrovec M, Trilar T, Avsic-Zupanc T: The molecular evidence of Babesia microti infection in small mammals collected in Slovenia. Parasitol 2003, 126:113-117.

27. Hersh MH, Tibbetts M, Strauss M, Ostfeld RS, Keesing F: Reservoir competence of wildlife host species for Babesia microti. Emerg Infect Dis 2012, 18:1951-1957.

28. Kallio ER, Begon M, Birtles RJ, Bown KJ, Koskela E, Mappes T, Watts PC: First report of Anaplasma phagocytophilum and Babesia microti in rodents in Finland. Vector Borne Zoonotic Dis 2014, 14:389-393.

29. Rar VA, Epikhina TI, Livanova NN, Panov W, Pukhovskaia NM, Vysochina NP, Ivanov LI: [Detection of Babesia spp. DNA in small mammals and ixodic ticks on the territory of north Ural, west Siberia and far east of Russia]. Mol Gen Mikrobiol Virusol 2010:26-30.

30. Saito-Ito A, Yano Y, Dantrakool A, Hashimoto T, Takada N: Survey of rodents and ticks in human babesiosis emergence area in Japan: first detection of Babesia microti-like parasites in Ixodes ovatus. J Clin Microbiol 2004, 42:2268-2270

31. Sinski E, Bajer A, Welc R, Pawelczyk A, Ogrzewalska M, Behnke JM: Babesia microti: prevalence in wild rodents and Ixodes ricinus ticks from the
Mazury Lakes District of North-Eastern Poland. Int J Med Microbiol 2006, 296(Suppl 1):137-143.

32. Welc-Falęciak R, Bajer A, Behnke JM, Siński E: Effects of host diversity and the community composition of hard ticks (Ixodidae) on Babesia microti infection. Int J Med Microbiol 2008, 298(Suppl 1):235-242.

33. Yabsley MJ, Shock BC: Natural history of Zoonotic Babesia: role of wildlife reservoirs. Int J Parasitol Parasites Wildl 2013, 2:18-31.

34. Zamoto A, Tsuji M, Kawabuchi T, Wei Q, Asakawa M, Ishihara C: U.S.-type Babesia microti isolated from small wild mammals in Eastern Hokkaido, Japan. J Vet Med Sci 2004, 66:919-926.

35. Bown KJ, Lambin X, Telford G, Heyder-Bruckner D, Ogden NH, Birtles RJ: The common shrew (Sorex araneus): a neglected host of tick-borne infections? Vector Borne Zoonotic Dis 2011, 11:947-953.

36. Tołkacz K, Alsarraf M, Grzybek M, Behnke JM, Bajer A: Blood parasites of three co-occurring species of voles, Microtus arvalis, M. agrestis and $M$. oeconomus. In The 16th International Symposium 'Parasitic and allergic arthropods- medical and sanitary significance'. Kazimierz Dolny, Poland: Conference proceedings; 2013:98-99.

37. Goethert HK, Cook JA, Lance EW, Telford SR: Fay and Rausch 1969 revisited: Babesia microti in Alaskan small mammals. J Parasitol 2006, 92:826-831.

38. Bajer A, Harris PD, Behnke JM, Bednarska M, Barnard CJ, Sherif N, Clifford S, Gilbert FS, Sinski E, Zalat S: Local variation of haemoparasites and arthropod vectors, and intestinal protozoans in spiny mice (Acomys dimidiatus) from four montane wadis in the St Katherine Protectorate, Sinai, Egypt. J Zool 2006, 270:9-24.

39. Bajer A, Pawelczyk A, Behnke JM, Gilbert FS, Sinski E: Factors affecting the component community structure of haemoparasites in bank voles (Clethrionomys glareolus) from the Mazury Lake District region of Poland. Parasitol 2001, 122:43-54.

40. Bajer A, Welc-Faleciak R, Bednarska M, Alsarraf M, Behnke-Borowczyk J, Sinski E, Behnke JM: Long-Term Spatiotemporal Stability and Dynamic Changes in the Haemoparasite Community of Bank Voles (Myodes glareolus) in NE Poland. Microb Ecol 2014, 68:196-211.

41. Pawelczyk A, Bajer A, Behnke JM, Gilbert FS, Sinski E: Factors affecting the component community structure of haemoparasites in common voles (Microtus arvalis) from the Mazury Lake District region of Poland. Parasitol Res 2004, 92:270-284.

42. Turner CM: Seasonal and age distributions of Babesia, Hepatozoon, Trypanosoma and Grahamella species in Clethrionomys glareolus and Apodemus sylvaticus populations. Parasitol 1986, 93:279-289.

43. Goethert H, Telford SR 3rd: What is Babesia microti? Parasitol 2003, 127:301-309.

44. Nakajima R, Tsuji M, Oda K, Zamoto-Niikura A, Wei Q, Kawabuchi-Kurata T, Nishida A, Ishihara C: Babesia microti-group parasites compared phylogenetically by complete sequencing of the CCTeta gene in 36 isolates. J Vet Med Sci 2009, 71:55-68.

45. Behnke JM, Barnard CJ, Mason N, Harris PD, Sherif NE, Zalat S, Gilbert FS: Intestinal helminths of spiny mice (Acomys cahirinus dimidiatus) from St Katherine's Protectorate in the Sinai, Egypt. J Helminthol 2000, 74:31-43.

46. Behnke JM, Harris PD, Bajer A, Barnard CJ, Sherif N, Cliffe L, Hurst J, Lamb M, Rhodes A, James M, Clifford S, Gilbert FS, Zalat S: Variation in the helminth community structure in spiny mice (Acomys dimidiatus) from four montane wadis in the St Katherine region of the Sinai Peninsula in Egypt. Parasitol 2004, 129:379-398.

47. Blaschitz M, Narodoslavsky-Gfoller M, Kanzler M, Stanek G, Walochnik J: Babesia species occurring in Austrian Ixodes ricinus ticks. Appl Environ Microbiol 2008, 74:4841-4846.

48. Bonnet S, Jouglin M, L'Hostis M, Chauvin A: Babesia sp. EU1 from roe deer and transmission within Ixodes ricinus. Emerg Infect Dis 2007, 13:1208-1210.

49. Bonnet S, Jouglin M, Malandrin L, Becker C, Agoulon A, L'Hostis M, Chauvin A: Transstadial and transovarial persistence of Babesia divergens DNA in Ixodes ricinus ticks fed on infected blood in a new skin-feeding technique. Parasitol 2007, 134:197-207.

50. Matjila PT, Leisewitz AL, Oosthuizen MC, Jongejan F, Penzhorn BL: Detection of a Theileria species in dogs in South Africa. Vet Parasitol 2008, 157:34-40.

51. Tamura K, Stecher G, Peterson D, Filipski A, Kumar S: MEGA6: molecular evolutionary genetics analysis version 6.0. Mol Biol Evol 2013, 30:2725-2729.

52. Welc-Faleciak R, Bajer A, Bednarska M, Paziewska A, Sinski E: Long term monitoring of Babesia microti infection in BALB/c mice using nested PCR. Ann Agric Environ Med 2007, 14:287-290. 
53. Concannon R, Wynn-Owen K, Simpson VR, Birtles RJ: Molecular characterization of haemoparasites infecting bats (Microchiroptera) in Cornwall, UK. Parasitol 2005, 131:489-496.

54. Conrad PA, Kjemtrup AM, Carreno RA, Thomford J, Wainwright K, Eberhard M, Quick R, Telford SR 3rd, Herwaldt BL: Description of Babesia duncani n.sp. (Apicomplexa: Babesiidae) from humans and its differentiation from other piroplasms. Int J Parasitol 2006, 36:779-789.

55. Kjemtrup AM, Conrad PA: A review of the small canine piroplasms from California: Babesia conradae in the literature. Vet Parasitol 2006, 138:112-117.

56. Kjemtrup AM, Wainwright K, Miller M, Penzhorn BL, Carreno RA: Babesia conradae, sp. nov., a small canine Babesia identified in California. Vet Parasitol 2006, 138:103-111.

57. Williams BM, Berentsen A, Shock BC, Teixiera M, Dunbar MR, Becker MS, Yabsley MJ: Prevalence and diversity of Babesia, Hepatozoon, Ehrlichia and Bartonella in wild and domestic carnivores from Zambia, Africa. Parasitol Res 2014, 113:911-918.

58. Michael SA, Morsy TA, Montasser MF: A case of human babesiosis (preliminary case report in Egypt). J Egypt Soc Parasitol 1987, 17:409-410.

59. El-Bahnasawy MM, Khalil HH, Morsy TA: Babesiosis in an Egyptian boy aquired from pet dog, and a general review. J Egypt Soc Parasitol 2011, 41:99-108.

60. El-Bahnasawy MM, Morsy TA: Egyptian human babesiosis and general review. J Egypt Soc Parasitol 2008, 38:265-272.

61. Youssef Al, Uga S: Review of parasitic zoonoses in Egypt. Trop Med Health 2014, 42:3-14

62. Mazyad SA, Shoukry NM, El-Alfy NM: Efficacy of Ixodes ricinus as a vector of zoonotic babesiosis in Sinai Peninsula, Egypt. J Egypt Soc Parasitol 2010, 40:499-514

63. Mikhail MW, Soliman Ml, Abd el HA: Infestation rate of tick, mite and lice among rodent species in Menoufia governorate, Egypt. J Egypt Soc Parasitol 2010, 40:425-438.

64. Gerbillus dasyurus. [Www.iucnredlist.org]

65. Gandon S, Capowiez Y, Dubois Y, Michalakis Y, Olivieri I: Local Adaptation and Gene-For-Gene Coevolution in a Metapopulation Model. Proc Biol Sci 1996, 263:1003-1009.

66. Eizaguirre C, Lenz TL, Kalbe M, Milinski M: Rapid and adaptive evolution of MHC genes under parasite selection in experimental vertebrate populations. Nat Commun 2012, 3:621.

67. Felsenstein J: Confidence limits on phylogenies: an approach using the bootstrap. Evol 1985, 39:783-791.

68. Saitou N, Nei M: The neighbor-joining method: a new method for reconstructing phylogenetic trees. Mol Biol Evol 1987, 4:406-425.

69. Kimura M: A simple method for estimating evolutionary rates of base substitutions through comparative studies of nucleotide sequences. J Mol Evol 1980, 16:111-120.

doi:10.1186/s13071-014-0572-9

Cite this article as: Bajer et al:: Babesia behnkei sp. nov., a novel Babesia species infecting isolated populations of Wagner's gerbil, Dipodillus dasyurus, from the Sinai Mountains, Egypt. Parasites \& Vectors 2014 7:572.

\section{Submit your next manuscript to BioMed Central and take full advantage of:}

- Convenient online submission

- Thorough peer review

- No space constraints or color figure charges

- Immediate publication on acceptance

- Inclusion in PubMed, CAS, Scopus and Google Scholar

- Research which is freely available for redistribution

Submit your manuscript at www.biomedcentral.com/submit
Ciomed Central 